\title{
Alfalfa Survival and Vigor in Rangeland Grazed by Sheep
}

J.D. BERDAHL, A.C. WILTON, R.J. LORENZ, AND A.B. FRANK

\section{Abstract}

Few detailed comparisons have been made among alfalfa (Medicago spp.) cultivars and strains grazed in semiarid, rangeland environments. The objective of this study was to determine survival and vigor of alfalfa cultivars and experimental strains that were grown in association with rangeland grasses and grazed by sheep for 3 seasons. Three-month old seedlings of 5 cultivars and 6 experimental strains of winterhardy alfalfa were transplanted in June 1979 into grass sod on 0.9-m centers at a hillside site with a west-facing 16\% slope and Amor loam (Typic Haploboroll) soil. Dominant vegetation was western wheatgrass (Pascopyrum smithii (Rydb.) Löve. Syn: A gropyron smithii (Rydb.)], blue grama [Bouteloua gracilis (H.B.K.) Lag.], and smooth bromegrass (Bromus inermis Leyss.). For 3 seasons after the establishment year, each replicate was grazed in sequence for 2 weeks at a stocking rate of 48 yearling ewes/ha during summer and then mowed to a height of $10 \mathrm{~cm}$ in September. Only 5 of the 11 entries had greater than $50 \%$ survival after the third season. Three germplasm pools derived from local alfalfa plantings that had persisted more than 50 years in association with rangeland grasses were highest in survival, ranging from $72-74 \%$. Drylander and Roamer, 2 cultivars developed primarily for grazing in semiarid regions of western Canada, had 65 and $62 \%$ survival, respectively. Phenotypic variability found among surviving plants in this study will permit further genetic improvements in alfalfa for rangeland.

Interest in introducing alfalfa (Medicago spp.) into rangelands in western North America dates back to the early 1900 's when N.E. Hansen of the South Dakota Agricultural Experiment Station described alfalfa that he collected from the dry steppes of Siberia (Hansen 1909). Low seed production and seed shattering have been major factors limiting widespread commercial use of these hardy, creeping rooting accessions of yellow-blossomed 'Siberian' alfalfa (M. falcata L.) collected by Hansen. Oakley and Garver (1917) reported that the greatest value of $M$. falcata lies in its ability to form fertile hybrids [ $M$. sativa subsp. varia (Martyn) Arc.] with common, purple flowered alfalfa ( $M$. sativa $L$. subsp. sativa). They further state that, "those who fail to see beyond $M$. falcata's agronomic defects as it exists in the natural state are missing an opportunity in the field of plant breeding."Major sustained efforts to develop alfalfa cultivars for rangeland in the semiarid Northern Plains region of North America did not materialize until breeding programs were initiated by Agriculture Canada at Swift Current, Saskatchewan, in 1938 (Hcinrichs 1954) and by the South Dakota Agriculture Experiment Station in the 1940's (Adams 1956). Several winter and drought-hardy cultivars intended primarily for dryland grazing have been developed through these breeding programs. Most of the grazing management research and commercial usage of alfalfa in rangelands has been with seeded mixtures of alfalfa and various grass species (Lorenz 1982). Recent development of interseeding technology (Chisholm et al. 1982) has provided a means of introducing alfalfa into native range or into established stands of seeded grass.

This study compared survival and vigor of 11 alfalfa cultivars and experimental strains that were spaced-planted into rangeland and grazed by sheep for 3 seasons.

\footnotetext{
Authors are research geneticists, research agronomist, and plant physiologist, respectively, U.S. Department of Agriculture, Agricultural Research Service, Northern Great Plains Research Laboratory, P.O. Box 459, Mandan, ND 58554.

Statistical advice from Dr. D.S. Gill and technical assistance of J.L. Winters, R.M. Ballou, and R.A. Wald are gratefully acknowledged.

Manuscript accepted 24 May 1985.
}

\section{Materials and Methods}

Seedlings of 5 cultivars and 6 germplasm pools of winterhardy alfalfa (Table 1) were started in peat pots in the greenhouse in March 1979 and transplanted 3 months later into sod on $0.9-\mathrm{m}$ centers at a range site with a $16 \%$ west facing slope. The site was mowed to a height of $10 \mathrm{~cm}$ just prior to transplanting. Seedlings were hand watered immediately after transplanting and twice during August of the establishment year with sprinkler irrigation to encourage a high level of survival. No fertilizer was applied during the study. Soil was classified as an Amor loam (Typic Haploboroll), an upland soil fairly high in clay content typically found on slopes of $10-25 \%$. Associated vegetation was primarily western wheatgrass [Pascopyrum smithii (Rydb.) Löve. Syn: Agropyron smithii Rydb.], blue grama [Bouteloua gracilis (H.B.K.) Lag.], and smooth bromegrass (Bromus inermis Leyss.).

Each of 4 replications was subdivided on a grid pattern into 144 5-plant $\times$ 5-plant cells. Each cell contained 4 plants of the C-3, South Dakota, Mandan I, and Mandan II germplasm pools and 1 plant of each of the 7 remaining entries for a total of 23 plants per cell. Plants from all entries were randomly distributed within each cell with 2 of the 25 positions left vacant. We anticipated that the C-3, South Dakota, Mandan I, and Mandan II germplasm pools would contain unique genotypes that would be adapted to rangeland grazing. Thus, representation of these 4 germplasm pools in the plant cells was 4 times higher than the remaining 7 entries. This provided a valuable base population from which outstanding individual genotypes could be selected.

In 1980 through 1982, each replicate was grazed in sequence for 2 weeks at a heavy stocking rate of 48 yearling ewes/ha, beginning about 1 June with the first replicate and terminating about 1 August with the fourth replicate. The grazing sequence for the replicates was the same each season. Forage utilization after the 2-week period of grazing was approximately $75 \%$. All replicates were mowed to a height of $10 \mathrm{~cm}$ in September each year. Annual precipitation was near the long-term average of $42 \mathrm{~cm}$ for the duration of the study, but early season precipitation was low in 3 years. March through June precipitation, which averages $20 \mathrm{~cm}$, was 44,37 , and $56 \%$ of normal for 1979, 1980, and 1981, respectively.

Survival and vigor of each plant was recorded in August of the establishment year and after approximately 30 days regrowth had occurred following grazing in the 3 subsequent years. Vigor of live plants was visually rated on a scale from 1-9 where a score of 1 indicated highest vigor and 9 indicated a plant that appeared nearly dead. Survival and vigor data were analyzed using a randomized complete block design. Data included in the analysis were one plant, randomly selected by computer, from each of the 4 germplasm pools with 4 plants per cell and 1 plant from each of the 7 remaining entries that were represented by a single plant in each cell. This resulted in 144 plants per entry from the 1445 -plant $X$ 5-plant cells in each of 4 replications.

Not all portions of the study had uniform survival due to differences in soil type, associated vegetation, grazing intensity, and other factors. The 5-plant $\times 5$-plant cells were sorted into the following overall survival categories based on survival data recorded after 3 seasons of grazing: Category I (0-8 plants surviving within each cell), Category II (9-13), Category III (14-18), and Category IV (19-23). Summing over replications, the number of cells in Categories I through IV were 77, 158, 231, and 83, respec- 
Table 1. Description and origin of cultivars and germplasm pools.

\begin{tabular}{ll}
\hline \hline Entry & \multicolumn{1}{c}{ Description } \\
\hline Drylander & 15 clone synthetic. Approximately $70 \%$ creeping rooted. Slow recovery \\
& and very persistent. Intended for overseeding rangeland, permanent or \\
semipermanent pasture, or single-cut hay crop in semiarid regions of \\
western Canada and northern U.S.
\end{tabular}

Roamer

Spredor 2

Ramsey

Ladak 65

KS-10 Germplasm Pool

C-3 Germplasm Pool

Alaska Germplasm Pool

South Dakota Germplasm Pool

Mandan I and Mandan II Germplasm Pools
7 clone synthetic. Approximately $60 \%$ creeping rooted. Faster recovery and higher seed yield than Drylander, but slightly less hardy. Intended use same as Drylander.

Selected for creeping root habit, persistence, bacterial wilt resistance, seed production, and vigor. Intended primarily for overseeding rangeland, permanent or semipermanent pasture, and dryland hay production in northern areas.

4 clone synthetic. Selected for winterhardiness and multiple pest resistance. Area of adaptation similar to Vernal.

49 clone synthetic. Derived from older commercial stands of certified Ladak. Higher levels of bacterial wilt resistance and more persistent than Ladak in long-ferm stands.

95 clone synthetic derived from Ladak. Resistant to spotted alfalfa aphid (Therioaphis maculata Buckton), pea aphid (Acyrthosiphon pisum Harris), and bacterial wilt [Corynebacterium insidiosum (McCull.) H.L. Jens]. KS-10 has more rapid recovery and is less dormant than the parent variety, Ladak.

Genetically diverse population derived by intermating selections from 63 cultivars, experimental synthetics, and germplasm pools adapted to the central and northern Great Plains. Intended as a germplasm source for breeding cultivars adapted to semiarid regions.

Germplasm source population of Medicago falcata that has persisted for over 50 years at Palmer, Alaska.

Germplasm source population derived by bulking open pollinated seed of selections from alfalfa-grass stands that have been grazed over 50 years at the N.G. Smith ranch, Perkins County, SD and the R. Schnell ranch, Adams County, ND. Primarily $M$. falcata tracing to introductions of N.E. Hansen.

Two germplasm source populations derived by bulking open pollinated seed of selections from alfalfa-grass stands at two sites. These alfalfagrass stands have persisted under light grazing and hay production since 1922 at the Northern Great Plains Research Laboratory, Mandan, ND., and trace to bulk seed from source nurseries of N.E. Hansen. In each population, approximately $20 \%$ of the plants have typical $M$. falcata characteristics, $50 \% \mathrm{M}$. sativa subsp. varia, and $30 \% \mathrm{M}$. sativa $\mathrm{L}$. subsp. sativa.
Origin

Agriculture Canada, Swift Current, Saskatchewan (Heinrichs 1971)

Agriculture Canada, Swift Current, Saskatchewan (Heinrichs 1967).

Northrup, King Co. (W.J. Knipe', personal communication)

Minnesota Agr. Exp. Sta. and USDA, ARS (Elling et al. 1973).

Montana Agr. Exp. Sta. (Eslick et al. 1968).

Kansas Agr. Exp. Sta. and USDA, ARS (Sorensen et. al. 1975)

Colorado Agr. Exp. Sta. and USDA, ARS (Townsend et al. 1976)

Alaska Agr. Exp. Sta. and USDA, ARS (Roscoe L. Taylor ${ }^{2}$, personal communication)

USDA, ARS, Mandan, ND

USDA, ARS, Mandan ND

'W.J. Knipe, Northrup, King Research Center, P.O. Box 1406, Woodland, CA 95695.
'Roscoe L. Taylor, USDA, ARS, Agricultural Experiment Station, P.O. Box AE, Paimer, AK 99645.

tively. Twenty-seven cells out of a total of 576 had less than $50 \%$ survival in the establishment year and were not included in statistical analyses. Number of surviving plants was evaluated in an $11 \times 4$ contingency table ( 11 entries $\times 4$ survival categories) with a chi square test for independence. The null hypothesis was that all entries had the same survival, relative to each other, in each of the 4 survival categories.

\section{Results and Discussion}

The Alaska germplasm pool, Spredor 2, and Ramsey had low survival and vigor during the establishment year relative to other entries (Table 2). Factors other than slow seedling development typical of $M$. falcata may have contributed to low survival of the Alaska germplasm pool. The South Dakota germplasm pool, primarily $M$. falcata but with some introgression from $M$. sativa, had high survival in the establishment year. The Alaska and South Dakota germplasm pools trace to a different genetic base (Rumbaugh 1980), and the relatively cool, moist environment in Alaska imposed different selection pressures than would be found in the semiarid environment of the northern Great Plains. The other 2 entries with relatively low survival in the establishment year, Spredor 2 and Ramsey, also were developed in more humid environments where little selection pressure likely was exerted for establishment capability under semiarid conditions.

Only 5 entries had above $50 \%$ survival after 3 seasons of grazing (Table 2). The Mandan I and II and South Dakota germplasm pools were nearly equal in survival and ranked above all other entries. The source material for these 3 germplasm pools had been subjected to some degree of grazing and had persisted in association with grass in local rangeland environments for over 50 years (Table 1). Some reseeding of the original $M$. falcata source material had undoubtedly occurred. The 2 Mandan germplasm pools had more introgression of $\boldsymbol{M}$. sativa than the South Dakota germplasm pool. Drylander and Roamer, while relatively high in survival, ranked lower than the Mandan and South Dakota germplasm pools. Ramsey, a winterhardy cultivar developed for hay production, was significantly lower in survival than the other entries. Vigor scores of plants surviving 3 seasons of grazing did not differ appreciably among entries except for Ramsey, which was significantly less vigorous than most of the others. 
Table 2. Survival percentages and vigor scores in the establishment year and after three seasons of grazing by sheep for 11 alfalfa cultivars or experimental strains transplanted on $0.9 \mathrm{~m}$ centers at a grassland site near Mandan, ND.

\begin{tabular}{|c|c|c|c|c|}
\hline \multirow[b]{2}{*}{ Entry } & \multicolumn{2}{|c|}{ Establishment year } & \multicolumn{2}{|c|}{ Grazed three seasons } \\
\hline & $\begin{array}{c}\text { Survival Per- } \\
\text { centagel }\end{array}$ & $\begin{array}{l}\text { Vigor } \\
\text { Score }\end{array}$ & $\begin{array}{l}\text { Survival Per- } \\
\text { centage }\end{array}$ & $\begin{array}{l}\text { Vigor } \\
\text { Score }\end{array}$ \\
\hline $\begin{array}{l}\text { Mandan I Germ- } \\
\text { plasm Pool } \\
\text { South Dakota } \\
\text { Germplasm }\end{array}$ & 93 & 6.5 & 74 & 6.0 \\
\hline $\begin{array}{l}\text { Pool } \\
\text { Mandan ll Germ- }\end{array}$ & 92 & 6.8 & 73 & 6.1 \\
\hline plasm Pool & 92 & 6.7 & 72 & 6.1 \\
\hline Drylander & 92 & 6.6 & 65 & 6.2 \\
\hline $\begin{array}{l}\text { Roamer } \\
\text { C-3 Germ- }\end{array}$ & 93 & 6.6 & 62 & 6.7 \\
\hline $\begin{array}{l}\text { plasm Pool } \\
\text { Alaska Germ- }\end{array}$ & 96 & 6.1 & 50 & 6.4 \\
\hline plasm Pool & 64 & 7.7 & 46 & 6.2 \\
\hline $\begin{array}{l}\text { Spredor } 2 \\
\text { KS-10 Germ- }\end{array}$ & 76 & 7.7 & 43 & 6.7 \\
\hline $\begin{array}{l}\text { plasm Pool } \\
\text { Ladak } 65\end{array}$ & $\begin{array}{l}93 \\
91\end{array}$ & $\begin{array}{l}6.4 \\
6.4\end{array}$ & $\begin{array}{l}43 \\
42\end{array}$ & $\begin{array}{l}6.7 \\
6.5\end{array}$ \\
\hline Ramsey & 66 & 7.7 & 30 & 7.2 \\
\hline$S_{\bar{y}}$ & 2.7 & 0.2 & 4.0 & 0.2 \\
\hline LŚ. $D_{00}$ & 7.7 & 0.5 & 11.7 & 0.6 \\
\hline
\end{tabular}

'Each entry represented by 549 transplants.

2Vigor score ranges from $1-9$ where $I=$ most vigorous; dead plants not scored.

'Survival of 549 transplants per entry and vigor of live plants were assessed after 30 days regrowth had occurred following grazing.

The 5-plant $\times 5$-plant cells provided 549 microenvironments to compare entries for survival. Survival, expressed as a percentage of establishment year stands, was tabulated for each entry within 4 survival categories for plant cells (Table 3). A significant chi square test for independence indicated that the entries did not maintain the same survival, relative to each other, in all 4 survival categories.
The Alaska germplasm pool had relatively high survival when survival of other entries was low, but did not maintain this advantage in the categories with higher survival. Once established, the Alaska germplasm pool, with slow regrowth and early fall dormancy, was able to survive in microenvironments where less hardy germplasm did not. In microenvironments with high overall survival, most of the other entries had taller plants with faster regrowth than the Alaska germplasm pool and were equal or higher in survival. Survival of Ramsey was below the survival category mean in all categories. Ramsey is winterhardy (Elling et al. 1973), but the cultivar apparently was not well adapted to stresses associated with grazing and/or drought in this study. The Mandan I and II and South Dakota germplasm pools were apparently suited for grazing over the entire range of microenvironments found in this study, since they survived well in all 4 survival categories. Drylander, with slower regrowth than Roamer, had higher survival in Category $I$. Drylander and Roamer both ranked slightly above the survival category mean in the remaining 3 categories.

Stress factors that are representative of rangeland conditions are important in identifying superior alfalfa genotypes suited to rangeland grazing. Keller (1948) pointed out that selection of range plants should be made under conditions that represent, as closely as possible, the area where the species is expected to be used. Ries (1982) reported that alfalfa has to survive and produce under limited management in a wide variety of rangeland environments. He stated further that alfalfa is selectively grazed by livestock and wildlife and, even under proper stocking rates, grazing pressure could be quite heavy. Alfalfa in our study was subjected to a number of different stress factors typical of rangeland conditions. In addition to stress associated with grazing, other factors imposing selection pressure for survival on the alfalfa included a $16 \%$ west-facing slope, competition from associated vegetation, low early season precipitation in 3 out of 4 years, and the September clippings which probably resulted in low levels of carbohydrate reserves in root and crown tissue (Smith 1972) and reduced snow cover during winter.

The creeping rooted trait described by Heinrichs (1963) that enables plants to produce new shoots from horizontal rootstalks

Table 3. Survival percentages and ranking within four survival categories for 11 alfalfa cultivars or experimental strains transplanted on $0.9 \mathrm{~m}$ centers at a grassland site and grazed by sheep for three seasons near Mandan, ND.

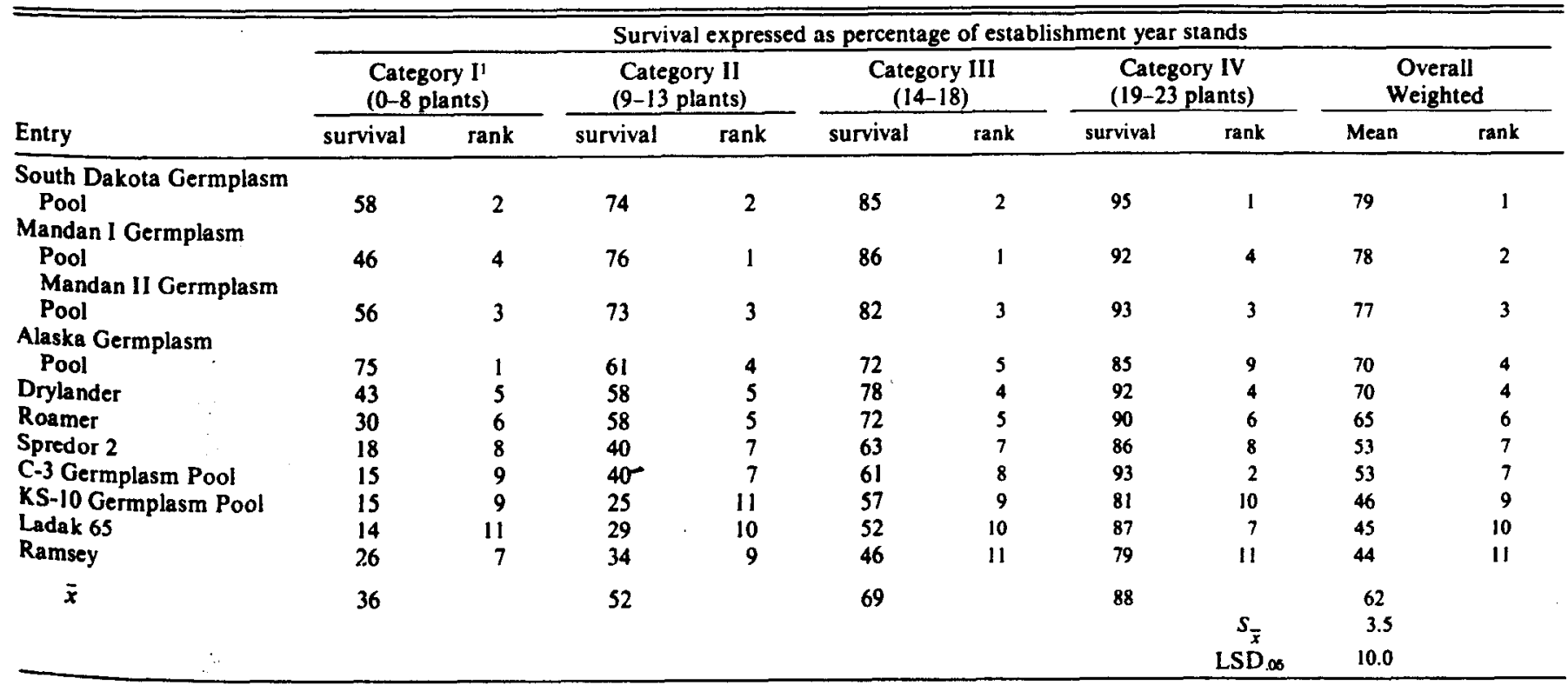

'Survival categories based on number of live plants in individual plant cells recorded after 30 days regrowth had occurred following the third season of grazing. Survival $X^{2}$ caries I, II, III, and IV were represented by $77,158,231$, and 83 plant cells, respectively.

$X^{2}$ for independence $=96.0, P=0.0001^{*}$ 30d.f. [from $11 \times 4$ contingency table ( 11 entries $\times 4$ survival categories) of number of surviving plants]. 
may be an important survival mechanism for alfalfa in rangeland. Other traits that Heinrichs (1975) found important to survival of alfalfa in semiarid rangeland of western Canada include deep-set crowns that protect plants from trampling, dormancy during long dry and cold periods, and slow regrowth after grazing. It was apparent in our study that plants with rapid regrowth after grazing and fall cutting tended to have low survival. Smith (1972) reported that root reserves in alfalfa are rapidly depleted by frequent cutting. Thus, slow regrowth could be an important factor contributing to maintenance of carbohydrate root reserves in rangeland alfalfa under grazing pressure.

Our primary breeding objectives in developing alfalfa for rangeland are high establishment capability and high levels of persistence under grazing. High regrowth potential under grazing and long-term persistence may be mutually exclusive. We are encouraged by the phenotypic variability found among surviving plants in this study and are optimistic that further genetic improvements can be made in alfalfa germplasm for rangeland.

\section{Literature Cited}

Adams, M.W. 1956. Creeping alfalfa. South Dakota Farm Home Res. 7:74-77

Chisholm, T.S., F.R. Vigil, T.M. Klosterman, and G. Orcutt. 1982. Interseeding and plans for SDSU's new machine-for better pasture production. South Dakota Agr. Exp. Sta., Bull. B680.

Elling, L.J., F.I. Frosheiser, D.K. Barnes, and R.D. Wilcoxon. 1973. Registration of Ramsey Alfalfa. Crop Sci. 13:769.

Eslick, R.F., J.L. Krall, and A.E. Carleton. 1968. Registration of Ladak 65 Alfalfa. Crop Sci. 8:513.
Hansen, N.E. 1909. The wild alfalfas and clovers of Siberia, with a perspective view of the alfalfas of the world. USDA, Bur. Plant Ind. Bull. 150.

Heinrichs, D.H. 1954. Developing creeping-rooted alfalfa for pasture. Can J. Plant Sci. 34:269-280.

Heinrichs, D.H. 1963. Creeping alfalfas. Adv. Agron. 15:317-337.

Heinrichs, D.H. 1967. Roamer alfalfa. Can. J. Plant Sci. 47:220-221.

Heinrichs, D.H. 1971. Drylander alfalfa. Can. J. Plant Sci. 51:430-432.

Heinrichs, D.H. 1975. Potentials of legumes for rangelands, p. 50-61. In: Robert S. Campbell and Carlton H. Herbel (ed.) Improved Range Plants. Range Symposium, Series I. Soc. Range Manage.. Denver. CO.

Keller, W. 1948. Wanted: A paragon for the range. p. 347-35I. In: Grass. USDA Yearbook Agr.

Lorenz, R.J. 1982. Alfalfa in western grazing management systems, p. 1-3 In: Alfalfa for dryland grazing. USDA, ARS. Agr. Inf. Bull. 444. U.S. Gov. Printing Office. Washington, D.C.

Oakley, R.A., and S. Garver. 1917. Medicago falcala, a yellow-flowered alfalfa. USDA, Bur. Plant Ind. Bull. 428.

Ries, R.E. 1982. Environmental factors and alfalfa persistence in dryland pastures and rangeland, p. 4-7. In: Alfalfa for dryland grazing. USDA. ARS. Agr. Inf. Bull. 444. U.S. Gov. Printing Office. Washington. D.C. Rumbaugh, M.D. 1980. N.E. Hansen's contributions to alfalfa breeding in North America. South Dakota Agr. Exp. Sta. Bull. B665.

Smith, Dale. 1972. Cutting schedules and maintaining pure stands, p. 48 1-496. In: C.H. Hanson (ed.) Alfalfa science and technology. Agron Mono. 15. Amer. Soc. Agron., Madison, Wis.

Sorensen, E.L., H.L. Hackerott, and T.L. Harvey. 1975. Registration of KS-10 pest-resistant alfalfa germplasm. Crop Sci. 15:105.

Townsend, C.E., W.R. Kehr, E.L. Sorensen, M.D. Rumbaugh, M.W. Pedersen, D.K. Barnes, G.A. Rogler, and and C.H. Hanson. 1976. Registration of C-3 alfalfa germplasm. Crop Sci. 16:446. 